\title{
IMPACT OF EU FUNDS ON CURRENT STATUS AND PROSPECTS OF ORGANIC FARMING IN POLAND
}

\author{
Aleksandra Jezierska-Thole ${ }^{1}, \mathrm{PhD}$, Miroslaw Biczkowski ${ }^{2}, \mathrm{PhD}$ \\ Nicolaus Copernicus University, Faculty of Earth Sciences, Departmentof Spatial Planning and Tourism
}

\begin{abstract}
The analysis of the status of organic farms in Poland in the period of 2003-2016 showed an increase in both the number and the acreage of agricultural holdings. As of 2004, high dynamics of growth was observed, which was related to Poland's accession to the EU and implementation of the CAP and the national Environmental Management Scheme. The aim of this paper is to present growth tendencies in and aid measures for organic farming. The analysis demonstrates the dynamics in the number organic farms and the acreage of organic crops on the basis of the data of the Central Agricultural and Food Quality Inspection (GIJHARS) and the Agency for Restructuring and Modernisation of Agriculture (ARMA). The conclusions that can be drawn from the studies demonstrate that the development of organic farming is highly dependent on the amount of EU funds. Financial support coming from the budget of the European Community is effectuated through consecutive RDP editions (2004-2006, 2007-2013 and 2014-2020). The dynamics of growth in organic farming during the CAP implementation stage indicates that the level of support from the EU is the major determinant of growth in organic farming in Poland. The period of 2003-2016 was characterized by a ten-fold increase in the number of organic farms (from 2.286 to 23.375) and the acreage of organic crops (from 61.2 thousand ha to 537 thousand ha).
\end{abstract}

Keywords: organicfarms, funds EU, RDP, Poland

JEL code: 013, Q10

\section{Introduction}

Organic farming is nowadays one of the fastest growing branches of agriculture in the world, particularly in the European Union (EU). The term 'organic farming' was acknowledged in the EU legislation as a synonym of older terms deriving from historic names of agricultural production models: bio-dynamic agriculture (Koepfi Plato, 2001; Grykien, 2005) organic agriculture (Vogt, 2000; Goklany, 2002), agriculture biologique (Yussefi, 2010). Moreover, there appear also other terms, such as alternative and non-conventional agriculture (Seufert, Ramankutty, Foley, 2012). The growth of organic farming is connected to a destructive impact of conventional agriculture on the environment (Lamine, 2011), e.g. pollution of ground and subterranean water with nitrogen compounds, and over-production of food in developed countries. Whereas the aim of organic production is to protect the environment - soil, water and landscape - and to obtain high-quality crops (Tilman et al., 2001). This should be done by eliminating chemical technologies from agricultural production (Lairon, 2010; Kozlowski, 2009). Maintaining the balance between resources and economic demands (Stawicka, Szymczak-Piatek, Wieczorek, 2004) subscribes into the concept of sustainable development (Goldberger, 2011) and brings a great many benefits for the natural environment and society (Pearce, Turner, 1990). Organic farming in Poland is growing very dynamically. In the period of 2003-2016, the number of organic farms grew by more than 10 times: from 2.286 to 23.375. Similar intensity of growth is noted for the agricultural acreage (AA) under organic crops: from 61.2 thousand ha to 537 thousand ha. At present, they constitute about $4 \%$ of the total agricultural acreage in Poland (Jezierska-Thole, Rudnicki, Kluba, 2016). The growth of organic farming is affected by natural, social and economic conditions, including - first and foremost - financial instruments available in form of EU funds. Financial support coming from 
the budget of the European Community is effectuated through consecutive RDP editions (2004-2006, 2007-2013 and 2014-20201).

The aim of this paper is to present growth tendencies in and aid measures for Polish organic farming in the period of 2003-2016. It applies both to the number of organic farms and to the agricultural acreage (AA) dedicated for organic crops. The analysis was based on the materials and data by the Central Agricultural and Food Quality Inspection (GIJHARS) (number of organic farms and crops acreage) and the Agency for Restructuring and Modernisation of Agriculture (data related to the EU programmes). The period of time which has been covered by the research shows the state of organic farming in the run-up to Poland's accession to the EU (2003) and after the financial closure of the 2007-2013 perspective.Therefore, it can be clearly noticed how the EU instruments affect the growth of Polish organic farming.

\section{Material and methodology of research}

The analysis presents the state and possibilities of development of organic farms in Poland. The basic administrative unit accepted for the study was the region (region). The research period concerned the years 2003-2016. This is the time to adapt national agricultural policy to EU standards. Since 2004, the implementation of the Common Agricultural Policy (CAP) has begun, mainly through RDP (2004-2006, 2007-2013, 2014-2020). Therefore, there were large possibilities of co-financing organic farming.

This publication is "resultant statistical information" containing data on organic farms. Statistical material was obtained on the basis of reports of the Main Inspectorate of Trade Quality of Agriculture and Food (IJHARS), ARMA data and own empirical research. Descriptive and comparative studies were used and the results are presented in graphical form. The analysis covered the following research stages:

- presentation of the development of organic farms and the possibility of subsidizing organic farms from EU funds and the national budget;

- showing the state and changes in the number and area of organic farms in 2003-2016;

- an attempt to assess the impact of EU funds (RDPs) on the increase in the number and area of organic farms;

- In order to determine the correlation between the allocation of EU funds and the increase in the number of organic farms, Pearson's linear correlation coefficient was applied.

\section{Support for Polish organic farming in the periods of 2004-2006 and 2007-2013}

The first organic farm in Poland was set up in the 1930s. The bio-dynamic method of land cultivation was introduced by Stanislaw Karlowski, a Senator of the $2^{\text {nd }}$ Republic of Poland, in his estate in Szelejewo near Gostyn. In socialism, organic farming did not matter much. Only in 1986-1987 a pioneering group of farmers started to transform their agricultural holdings into organic farms. In the 1990s, the first Association of Organic Food Producers was founded; it granted 27 certificates in 1990 (Jezierska-Thole, Biczkowski 2013). Organic farming was first subsidised by the state in 1998. Initially, there were only subsidies to the costs of organic farm management, but in 2000, subsidies to the acreage of organiccrops were introduced. Currently, financial support for organic farming comes from two sources, i.e. from the national budget and the EU budget (Golinowska, Adamska, 2014). The procedures for granting and paying state subsidies

${ }^{1}$ According to the procedures of implementing the financial support policy of the EU, the actual implementation time span is 2 years (" $\left.n+2 "\right)$ after the completion of a particular perspective (e.g. the settlement of the RDP 2007-2013 funds was in fact finished in 2016) 
are provided for by the Regulation of the Ministry of Agriculture (Regulation of the Ministry of Agriculture and Rural Development of 30 May 2010). Until 2014 the state support for organic farming included: subsidies to costs of farm management, research into organic farming, coordination of consulting and running an exemplary organic farm, publication of training materials, analysis of the amount of prohibited substances (pesticides) in crops (Jezierska-Thole, Biczkowski, 2017).

Since Poland's accession to the European Union (2004) - thus, since becoming subject of the Common Agricultural Policy (CAP) - organic farmers have been able to participate in the Environmental Management Scheme, while since 2007, they have been able to take advantage of the RDP 2007-2013 measure 'organic farming'. Both forms of support offer applicants subsidies to organic production. In 2004, 3.654 agricultural holdings applied for subsidies to cost management. The amount paid for this purpose was 2.813 thousand PLN, whereby the largest sum was granted to the Malopolskie voivodship (Fig. 1).

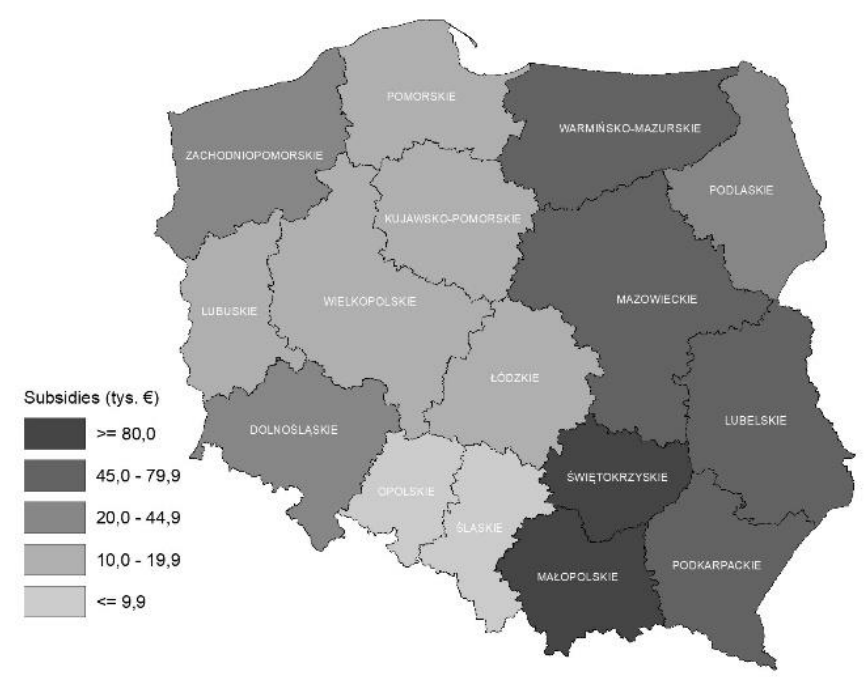

Source: authors' construction based on the data of Rolnictwo ekologiczne..., ARMA

Fig. 1. The amount of subsidy to control costs (tys. $\boldsymbol{C}$ )

In the implementation period of the RDP 2007-2013, organic farmers could obtain support from two axes (Rural..., 2007).

1) Axis I 'Improving the competitiveness of the agricultural and forestry sector' with the following measures:

- Participation of farmers in food quality scheme. The support was available only to producers of agricultural products dedicated for consumption (maximum of ca. $€ 240$ a year for a producer). In 2011, the European Commission agreed to increase the amount (up to ca. $€ 720$ ) for agricultural producers within the common system of food quality in organic farming.

- Information and promotion. It was supposed to improve the competitiveness of the agricultural and forestry sector and to give it more competitive advantage in the market. For financing information on and promotion of the products participating in food quality systems there were about $€ 10 \mathrm{mln}$. The scope of support covered not only agricultural yields but also comestibles.

2) Axis II 'Improving the environment and countryside' - measure 'Environmental Management Scheme', package 2 - 'organic farming'. The package included 12 feasible variants (Regulation by the Ministry of Agriculture and Rural Development of 28 February 2008). Generally, the budget available within the measures of the RDP 2007-2013 equalled $€ 39 \mathrm{mln}$ (Losz, 2014). 
In both of the completed programming periods (2004-2006 and 2007-2013), financial aid oscillated between $260 \mathrm{PLN} / \mathrm{ha}$ and $1.800 \mathrm{PLN} / \mathrm{ha}$, depending on the kind of crops and cultivation stage. Larger support was granted to farmers when their holdings were being adapted to organic farming, while lower support was given to holdings already with the certificate. Also, the RDP 2007-2013 introduced the support for cultivation of herbal and orchard plants (labour-intensive 1,800 PLN/ha and other - 1,540 PLN/ha) (Fig. 2).

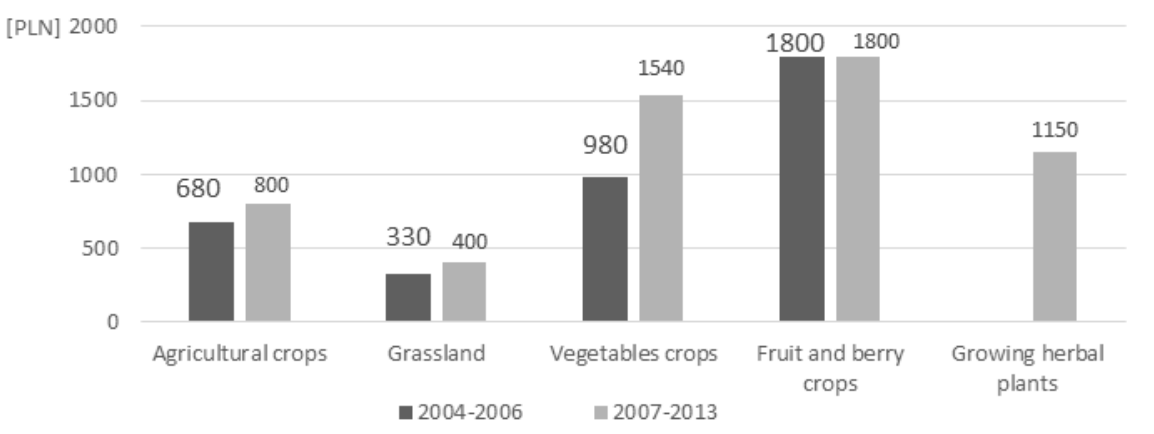

Source: authors' construction based on the data of Szanse i zagrożenia..., 2013, ARMA

Fig. 2. Subsidies(PLN) of organic farming (during conversion) in RDP 2004-2006 and 2007-2013

On account of the significant influence of organic farming on economic growth, social and cultural development, in 2004 the European Action Plan for Organic Food and Farming was created; it included the main instruments for growth of the pan-European organic sector (Action Plan..., 2007). One of its measures referred to CAP instruments and recommended full utilisation of the funds within the RDP 2007-2013 for the support of organic farming in the EU Member States. These aims covered, e.g. an increase in the number of organic farms and in the acreage under organic farming.

\section{Research results and discussion}

The development of organic farming in Poland may be divided into four stages (Fig. 3):

- initial period until 1998, when organic farming did not benefit from any financial support; with about 500 organic farms;

- period of 2000-2003, when the state budget reimbursed part of the costs of organic farm certification and insubstantial supplementary payments were made to agricultural acreage (AA). That led to a four-fold increase in the number of organic farms and agricultural acreage. Despite that, at the end of 2003 organic farms made merely $0.11 \%$ of all agricultural holdings and their acreage represented only $0.3 \%$ of the total AA in Poland (Jezierska-Thole, 2016);

- dynamic growth from 2004 to 2013, i.e. after Poland's accession to the EU and implementation of the CAP, as well as implementation of the national Environmental Management Scheme. This period saw a dynamic increase in the number of organic farms (from 3.760 to 26.598) and in their agricultural acreage (from 83 to 606 thousand ha) (Klos, 2001);

- period of 2014-2016 characterised by fluctuations related to the temporary reduction in the support for organic farming from the EU funds, as a result of which the number of farms fell slightly (down to 22.3 thousand) butbounced back later (23.4 thousand in 2016). 


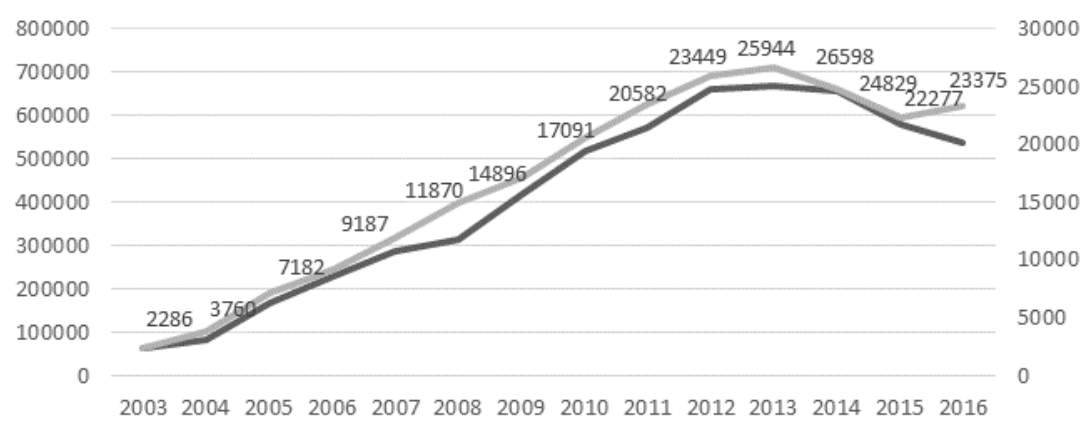

Source: authors' studies based on GIJHARS

Fig. 3. Number and agricultural area of organic farms in Poland in 2003-2016 A-number, B-agricultural area (ha)

The analysis of the ratio of organic farms at the regional level demonstrated that they appeared in high percentage in voivodships characterised by difficult natural conditions and agrarian fragmentation, i.e.: Malopolskie (18.5 \%), Swietokrzyskie (14.6 \%), Podkarpackie and Mazowieckie (11\%, respectively). Such a pattern proves that the financial support from the EU funds is particularly important for farmers operating in unfavourable natural conditions. It is further substantiated by a low value of the agricultural production area quality index ${ }^{1}$, much below the Polish average (67 points).In these areas, organic farming, besides being responsible for production, is also important owing to its protective function, i.e.: maintenance of environmental assets, biodiversity and cultural values. Recently the number of organic farms has grown in regions featuring a higher ratio of large holdings: Warminsko-Mazurskie $(17.8 \%)$, Podlaskie $(14.8 \%)$ and Zachodniopomorskie (11.5\%) voivodships (Fig. 4).

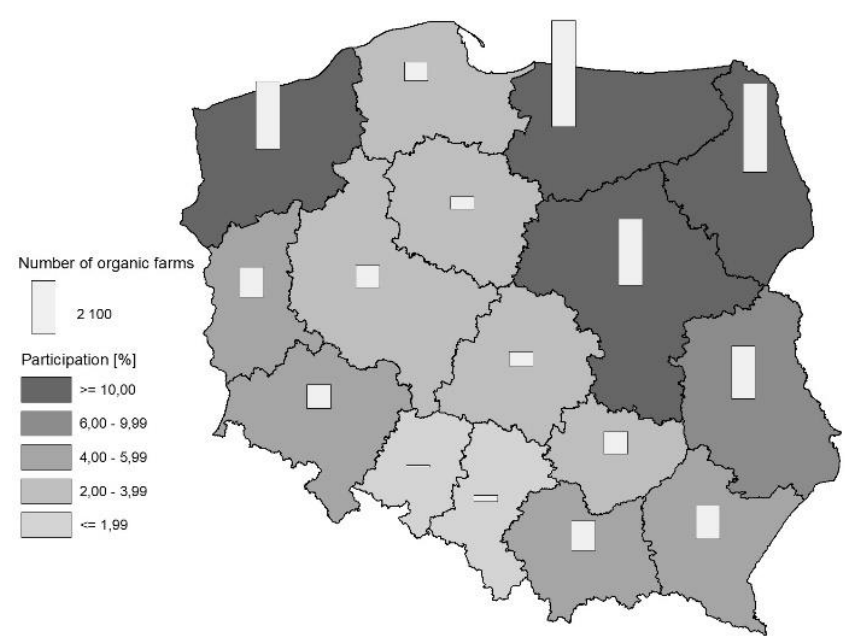

Source: authors' studies based on GIJHARS

Fig. 4. Number and participation of organic farms in by voivodeships in Poland in 2016

The largest increase in the number of organic farms was in 2005 and 2010 when, in relation to the previous year, the increment was of more than 3 thousand. These changes also bore on the acreage of organic farming. The years of 2009 and 2010 recorded the highest annual growth of agricultural acreage (by ca. 100 thousand ha). The years of 2014 and 2015 indicated the first decreases in the number of organic farms (by approx. 4 thousand) and their acreage. It was due to formal-legal criteria, changes in certification procedures, stricter requirements for organic food production processes, and discontinued subsidizing of new ventures from the EU funds (RDP 2007-2013 funds had already finished and PROW 2014-2020 had not been launched yet). In 2016,

1 Agricultural production area quality index (APAQI) - takes into account major elements of the natural environment: soil quality, agroclimate, landform and hydrographic conditions. It qualifies the area in terms of agricultural development. 
negative tendencies were stopped and the situation was stabilised; nowadays, we are witnessing a rising trend again (Fig. 5). An important objective of the study was to examine the strength of the relationship between the increase in the number of organic farms and the size of EU subsidies (under RDP 2007-2013) for farms conducting organic production. Analysis of interdependencies (carried out with the Pearson's linear correlation method for 2004 and 2016) between features showed a very strong relationship (0.902308) for amounts paid for organic farming, with the $\mathrm{R}^{2}$ determination coefficient (0.847).

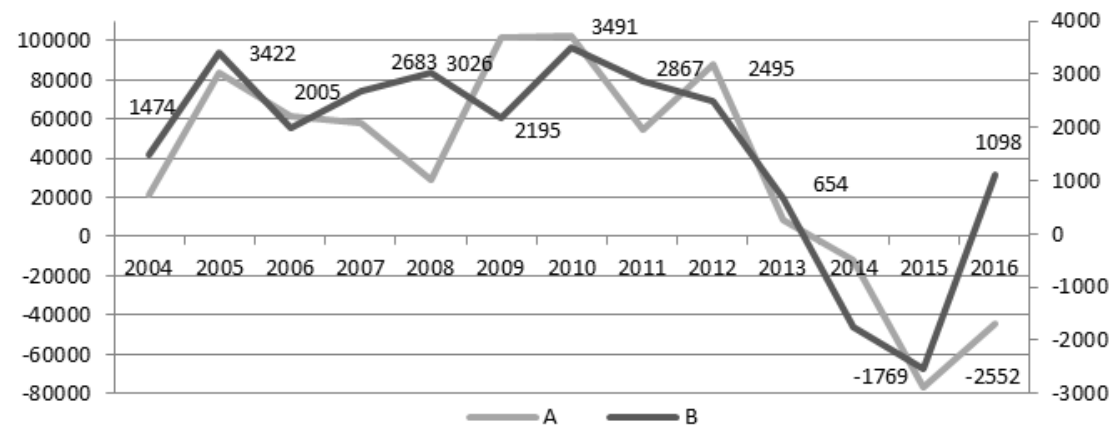

Source: authors' studies based on GIJHARS

Fig. 5. Growth in the number (A) and agricultural area in ha (B) of organic farms compared to the previous year in Poland in 2004-2016

At the regional level, the agricultural acreage under organic crops oscillates between 3 and 10 thousand ha (Opolskie, Slaskie and Lodzkie voivodships) and 100 thousand ha in the Zachodniopomorskie voivodship (Fig. 6). The average size of an organic farm equals 26.1 ha (an increase by 4.1 ha when compared with 2003) and is higher than that of a conventional farm (10.7 ha) by ca. 15 ha. A spatial analysis demonstrated that the highest ratio of large (50-100 ha) and very large (>100 ha) holdings was recorded in the following voivodships: Wielkopolskie (29.4\%), Opolskie (26.7\%), Lubuskie and Slaskie ( $24 \%$, respectively). On the other hand, a high ratio of small (below $10 \mathrm{ha}$ ) holdings was found in the following voivodships: Malopolskie (40\%), Swietokrzyskie and Lubelskie (20\%, respectively).

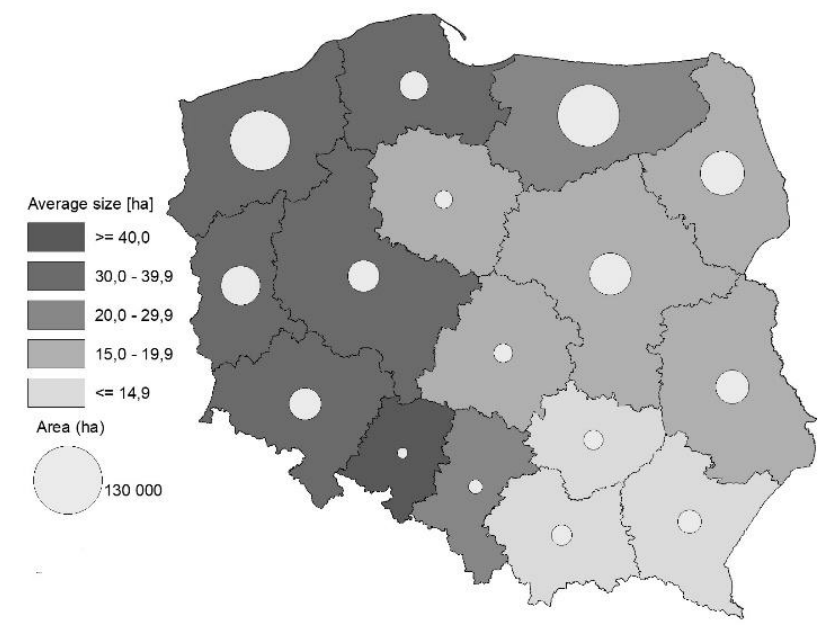

Source: authors' studies based on GIJHARS

Fig. 6. Agricultural area and average size of organic agricultural land in Poland in 2016 (hectare)

Thanks to organic farming being supported with the EU financial instruments, in recent years Poland has been maintaining high dynamics of growth in organic farms.Taking into account the whole period under analysis (2003-2016), Poland is on the second position in the world when it comes to the dynamics of growth in the acreage of organic crops. As a result (according to the 
EUROSTAT data), in 2013 Poland was ranked third in the EU in terms of the number of organic farms. However, after the collapse of 2014 and 2015, it fell to the sixth position (Fig. 7). Italy is the leader, followed by Spain, France and Germany.

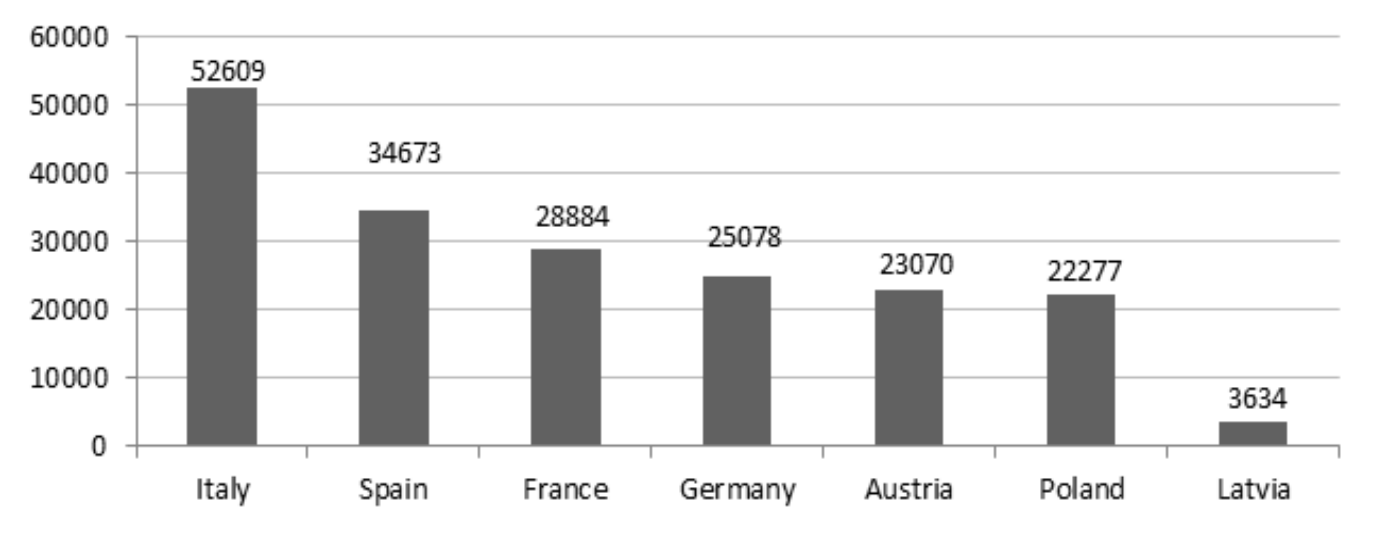

Source: authors' studies based on Eurostat and GIJHARS

Fig. 7. Number of organic farms in Europe in 2016

Although organic farming, as a new form of agricultural production, has already appeared in the 1920s, the period of its dynamic development is currently coming into existence. This is due to the fact that nature is changing. It is not currently perceived only as a reservoir of raw materials and a subordinate tool for people to achieve their goals, but as a holistic system in which people are one of its elements. Organic farming perfectly fits into the model of eco-development, becoming at the same time, the premise of multifunctional rural development.

\section{Conclusions}

1) The support for organic farming from the EU funds and the national Environmental Management Scheme largely contributed to the increase in the number and acreage of organic farms. The dynamics of growth in organic farming during the CAP implementation stage indicates that the level of support from the EU is the major determinant ofgrowth in organic farmingin Poland.

2) The period of 2003-2016 was characterized by a ten-fold increase in the number of organic farms and the acreage of organic crops. These farms are the most numerous in the following voivodships: Malopolskie, Podkarpackie, Lubelskie and Mazowieckie. In total, they made $50 \%$ of all organic farms in Poland. In the same time the agricultural acreage of organic farms surged from 61 thousand ha to 537 thousand ha, which is approx. $4 \%$ of the total agricultural acreage. The downward trend of 2014-2015 proves that if the level of support from the EU funds is lower, farmers reduce the acreage under organic crops.

3) The average size of an organic farm in Poland in 2016 exceeded 26 ha AA, with about 10.7 ha for conventional farms. In some voivodships, the size of an organic farm ranged from 10 ha (Malopolskie voivodship), through 43 ha (Wielkopolskie voivodship), up to 65 ha (Zachodniopomorskie voivodship).

4) Organic farms grow mostly in regions with unfavourable agri-technical conditions and a larger percentage of areas valued for their natural assets. In spite of the substantial increase in the AA and the number of organic farms, the volume of organic production in the Polish market is still insufficient.

5) The conclusions that can be drawn from the research demonstrate that the growth of organic farming is primarily dependent on the amount of EU funds. Therefore, it would be necessary to 
consider diversification of financial support systems in order to suit them to specific purposes, i.e. conservation of environmental assets or production of organic food.

\section{Acknowledgement.}

Thispaper was written in the framework of the researchproject of the National Science Centre [Narodowe Centrum Nauki] (no. DEC-2012/07/B/HS4/00364).

\section{References}

1. Goklany, I.M. (2002). The Ins and Outs of Organic farming. Science.Volume 298, 1889-1990.

2. Goldberger, J.R. (2011). Conventionalization, Civic Engagement, and the Sustainability of Organic Agriculture, Journal of Rural Studies, Volume 27, Issue 3, pp. 288-296. https://doi.org/10.1016/j.jrurstud.2011.03.002.

3. Golinowska, M., Adamska, H. (2014). Support for Organic Farming in Poland after 2004,J. Agrib. RuralDevel., 1(31), p. 31.

4. Grykien, S. (2005). Barriers to the Development of Organic Farming in Poland. In: E. Palka E. (Eds.) The functions of rural areas. Kielce: Publisher of the Swietokrzyska Academy, 63-71.

5. Jezierska-Thole, A.,Biczkowski, M. (2013). The Importance and Determinants of innovation in agriculture in Poland.Association of Agricultural and Agribusiness Economists, Volume 15, Issue 2, 124-131.

6. Jezierska-Thole, A. (2016). Spatial diversity of farms by size and region in Poland and Germany. Proceedings of the 2016 International Conference "Economic Science for Rural Development" No 42, Jelgava:LLUESAF, 21-22 April 2016, 235-243.

7. Jezierska-Thole, A., Rudnicki, R., Kluba, M. (2016). Development of energy crops cultivation for biomass production in Poland. Renew Sust. Energ. Rev., Volume 62, 534-545.

8. Jezierska-Thole, A.,Biczkowski, M.(2017). Financial Funds from European Union funds as a chance for the development of the sector of organic farms in Poland. Association of Agricultural and Agribusiness Economists, Volume 19, Issue 2, 95-102.

9. Klos, L. (2011). Organicfarming as an element of sustainable and sustainableagriculture,Economics and the Environment, No 1(39), 122-123.

10. Koepf, H., Plato, B.(2001). Die biologisch-dynamische Wirtschaftsweise im 20. Jahrhundert. Die Entwicklungsgeschichte der biologisch-dynamischen Landwirtschaft. Dornach: Verlag am Goetheanun, 5667.

11. Kozlowski, J. (2009). Ecologicalapproach in the planningmethodology - a safesolutionspace. Problems of Urban Development 4, 23-38.

12. Lairon, D. (2010). Nutritionalquality and safety of organic food. A review. Agronomy for Sustainable Development 30, 33-41.

13. Lamine, C. (2011). Transition pathways towards a robust ecologization of agriculture and the need for system redesign. Cases from organic farming and IPM. Journal of Rural Studies, Volume 27, Issue 2, 209219. https://doi.org/10.1016/j.jrurstud.2011.02.001.

14. Losz, K. (2014). How much money for farmers? Retrieved: http://www.naszdziennik.pl/ekonomia-polskawies/65388,ilepieniedzy-dla-rolni-kow.html [Access: 16.01.2015].

15. Main Inspectorate of Trade Quality of Agricultural and Food Products (GIJHARS). (2004). Organic farming in Poland in 2004. (2004). Warsaw, 6-14.

16. Ministry of Agriculture and Rural Development. (2007).Rural Development Program (RDP) 20072013.Warsaw: MRiRW,Retrieved: http://www.minrol.gov.pl/Wsparcie-rolnictwa/Program-RozwojuObszarow-Wiejskich-2007-2013. Access: 12.03.2017.Warsaw, Poland.

17. Ministry of Agriculture and Rural Development. (2008). Regulation of the Ministry of Agriculture and Rural Development of 28 February 2008 on detailed conditions and procedure for granting financial aid under the measure "Agro-environmental program" covered by the Rural Development Program for 2007-2013, Dz. U. No. 34, item 200.Warsaw, Poland.

18. Ministry of Agriculture and Rural Development. (2010). Regulation of the Council of Ministers of 30 May 2010 on detailed conditions and procedure for granting financial aid for supporting agri-environmental undertakings and improvement of animal welfare covered by the Rural Development Program, U. No. 174, item 1809. Warsaw, Poland.

19. Ministry of Agriculture and Rural Development. (2011).Action Plan for Organic Food and Farming in Poland for 2011-2014. Warsaw, Poland.

20. Pearce, D., Turner, K.R. (1990). Economics of Natural Resources and the Environment. New York, 35-42.

21. Seufert, V., Ramankutty, N. Foley, J.A. (2012). Comparing the fields of organic and conventional agriculture. Nature, 229-232.

22. Stawicka, J., Szymczak-Piatek, M., Wieczorek, J. (2004). Selected ecological issues. Opportunities and threats of Polish organic farming in the perspective of 2014-2020. Opinionsand Expertises of the OE210.Warsaw: SGGW.Analysis and Documentation Office Analysis and Thematic Studies Team of the Chancellery of the Senate of the Republic of Poland, 12-35. 
Proceedings of the 2018 International Conference "ECONOMIC SCIENCE FOR RURAL DEVELOPMENT" No 47

Jelgava, LLU ESAF, 911 May 2018, pp. 123-131 DOI 10.22616/ESRD.2018.014

23.Tilman, D., Fargione, J., Wolff, B., Antonio, C., Dobson, A., Howarth, R., Schindler, D., Schlesinger, W.H., Simberloff, D. Swackhamer, D. (2001). Forecasting agriculturally driven global environmental change. Science, Volume 13, Issue 292, 281.

24. Vogt, G. (2000). Entstehung und Entwicklung des okologischen Landbaus. In: Okologische Konzepte, Bad Durkheim: SOL, 6-14.

25. Yussefi, M. (2010). The World of organic agriculture: statistics and emerging trends 2008. Earthscan, 38-42. 